\title{
Kesalahan Berbahasa Mahasiswa Undip Studi Kasus Mahasiswa Fakultas Peternakan dan Pertanian
}

\author{
Suharyo \\ Fakultas Ilmu Budaya, Universitas Diponegoro \\ haryo.sastra@gmail.com
}

\begin{abstract}
This research aims to reveal language skills among students. To answer the research question, it was conducted using a questionnaire technique. The questionnaire (which contained 11 questions) was distributed to 40 FPP students, Diponegoro University, Semarang via online (ms team). Data were analyzed using PUEBI and Indonesian language standard grammar. The result, (1) the average respondent answered correctly at 54.54\%; (2) respondents who answered correctly about number 1 by 87.50\%; (3) for question number 2 as much as 0\% (4) for question number 3, respondents who answered correctly were 2.5\%; (5) for question number 4, amounting to 67.59\%; (6) for problem number 5, amounting to 85\%; (7) for question number 6 , amounting to $62.50 \%$, (8) for question number 7, amounting to $97.50 \%$, (9) for question number 8, amounting to 6\%, (10) for question number 9, amounting to 67 , 50\%; (11) for question number 10 only 40\%, and (12) for problem number 11 all respondents answered incorrectly.
\end{abstract}

Keywords: Mistakes; language; Undip students.

\section{Intisari}

Penelitin ini bertujuan mengungkap kemampuan berbahasa di kalangan mahasiswa. Untuk menjawab pertanyaan penelitian tersebut dilakukan dengan menggunakan teknik angket. Angket (yang berisi 11 pertanyaan) dibagikan kepada 40 mahsiswa FPP, Universitas Diponegoro, Semarang melalui daring ( $m s$ team). Data dianalisis dengan menggunakan PUEBI dan tata basa baku bahasa Indonesia. Hasilnya, (1) rata-rata responden menjawab benar sebesar 54,54\%; (2) responden yang menjawab benar soal nomor 1 sebesar 87,50\%; (3) untuk soal nomor 2 sebanyak $0 \%$ (4) untuk soal nomor3, responden yang menjawab benar sebesar 2,5\%; (5) untuk soal nomor 4, sebesar 67,59\%, (6) untuk soal nomor 5, sebesar 85\%; (7) untuk soal nomor 6, sebesar $62,50 \%$, (8) untuk soal nomor 7, sebesar 97,50\%, (9) untuk soal nomor 8, sebesar 6\%, (10) untuk soal nomor 9 , sebesar 67,50\%; (11) untuk soal nomor 10 hanya 40\%, dan (12) untuk soal nomor 11 semua responden jawabannya salah.

Kata kunci: Kesalahan; berbahasa; mahasiswa Undip.

\section{Pendahuluan}

Ejaan yang Disempurnakan (EYD) telah ditetapkan sejak tahun 1972 dan diperbarui menjadi Ejaan Bahasa Indonesia tahun 2015 dan Tata Bahasa Baku juga telah lama diluncurkan oleh Pemerintah melalui Badan Bahasa (semula bernama Pusat Pembinaan dan Pengembangan Bahasa). Artinya, jika dihitung dari 1972 maka sudah 48 tahun masa berlakuknya 
pedoman/panduan untuk berbahasa Indonesia terutama ragam tulis. Idealnya, jarang sekali ditemukan kesalahan baik dalam bidang ejaan (penulisan kata dan tanda baca, misalnya) maupun struktur kalimat. Benarkah demikian? Dari hasil sejumlah penelitian yang telah dilakukan ternyata masih banyak ditemukan kesalahan dalam berbagai aspek. Misalnya, aspek fonologis, morfologis, kalimat, dan tanda baca, serta penulisan kata. Ambil saja contoh hasil penelitian Monica Justiana (2018) dengan judul "Kesalahan Berbahasa pada Majalah Mimbar Edisi Juni Agustus 2016" yang dimuat pada jurnal Sim-Ki Pedagogia Vol. 02, No.3, Tahun 2018. Dari hasil penelitiannya, Justiana menemukan (1) banyak kesalahan penulisan ejaan, diksi, kalimat, dan paragraf dalam majalah Mimbar edisi Juni sampai dengan Agustus 2016. (2) kesalahan paling banyak adalah kesalahan penulisan ejaan. (3) masih ditemukan banyak sekali kesalahan pengetikan kata yang cukup fatal. (4) Pihak redaksi majalah Mimbar kurang teliti dalam melakukan proses pengeditan artikel-artikel baik dari isi maupun bahasanya.

Hasil penelitian Ariningsih, dkk. (2012) yang dimuat pada Jurnal BASASTRA, Vol.1, Nomor 1 menunjukkan bahwa (1) kesalahan bahasa Indonesia dalam karangan eksposisi siswa kelas X, (2) penyebab kesalahan, dan (3) upaya yang dilakukan oleh guru dan siswa untuk meminimalkan kesalahan berbahasa tersebut. Penelitian ini merupakan penelitian deskriptif kualitatif dengan sampel karangan siswa SMA Negeri 1 Karanganyar dan SMA Negeri Kebakkramat. Teknik sampling yang digunakan adalah purposive sampling. Teknik pengumpulan data yang digunakan adalah wawancara mendalam dan analisis dokumen. Teknik analisis data yang digunakan adalah model analisis interaktif yang meliputi empat komponen, yaitu pengumpulan data, reduksi data, penyajian data, dan verifikasi. Simpulan penelitian ini adalah sebagai berikut. Pertama, kesalahan bahasa yang sering terjadi dalam karangan siswa dibagi menjadi empat kesalahan: kesalahan ejaan, kesalahan diksi, kesalahan kalimat, dan kesalahan paragraf. Kedua, kesalahan bahasa yang sering terjadi dalam karangan eksposisi siswa disebabkan oleh beberapa faktor, antara lain: penguasaan bahasa siswa kurang, kurangnya contoh dari guru, pengaruh bahasa asing, kurangnya latihan menulis, dan kurangnya waktu menulis. Ketiga, upaya untuk mengurangi kesalahan berbahasa dalam karangan eksposisi siswa antara lain yaitu: meningkatkan penguasaan kaidah bahasa siswa, memperbanyak latihan mengarang, menerapkan teknik koreksi yang tepat, dan melaksanakan pembelajaran menulis dengan pendekatan proses. 
Secara ringkas Ariningsih, dkk. (2012) menyimpulkan pertama, unsur kebahasaan yang sering terjadi kesalahan berbahasa dalam karangan siswa dibedakan menjadi empat yaitu kesalahan aspek ejaan, diksi, kalimat, dan paragraf. Kedua, kesalahan berbahasa yang sering terjadi dalam karangan eksposisi siswa disebabkan oleh beberapa faktor antara lain : penguasaan kaidah bahasa siswa kurang, kurangnya contoh, terpengaruh bahasa asing, siswa kurang berlatih, dan kurangnya waktu mengarang. Ketiga, upaya untuk mengurangi kesalahan berbahasa dalam karangan eksposisi siswa antara lain yaitu : meningkatkan penguasaan kaidah bahasa siswa, memperbanyak latihan mengarang, menerapkan teknik koreksi yang tepat, dan melaksanakan pembelajaran menulis dengan pendekatan proses.

Hasil penelitian lain yang dikutip dalam tulisan ini adalah karya Johan (2018) yang dimuat dalam Jurnal Pendidikan Bahasa dan Sastra, Volume 18, Nomor 1, April 2018, dengan judul “Analisis Kesalahan Berbahasa Indonesia dalm Proses Diskusi Siswa Sekola Dasar”. Temuannya adalah kesalahan berbahasa Indonesia secara fonologis yang ditemukan dalam proses diskusi siswa VI SDN 1 Galagamba terdiri atas kesalahan pelafalan karena perubahan dan penghilangan bunyi tertentu. Kesalahan pelafalan karena perubahan fonem terjadi pada pelafalan perubahan bunyi vokal dan pelafalan perubahan bunyi diftong yang meliputi kesalahan perubahan bunyi vokal. Temuan lainnya, kesalahan berbahasa Indonesia secara morfologis yang ditemukan dalam proses diskusi siswa VI SDN 1 Galagamba terdiri atas kesalahan penggunaan afiks yang tidak tepat dan penghilangan afiks. Kesalahan penggunaan afiks yang tidak tepat meliputi kesalahan kesalahan penggunaan prefiks ter- yang tergantikan prefiks ke-, kesalahan penggunaan sufiks -nya, kesalahan penggunaan konfiks mem-kan, kesalahan penggunaan prefiks $n g e-$, dan kesalahan penggunaan penggunaan sufiks -kan. Kesalahan secara morfologis terjadi pada kesalahan penghilangan afiks yang terdiri atas kesalahan penghilangan prefiks ber-, dan kesalahan penghilangan prefiks me-, mem-.

Supriani dan Siregar (tanpa tahun) menjelaskan bahwa salah satu hambatan dalam komunikasi yaitu karena kurangnya keterampilan berbahasa. Wujud kekurangterampilan berbahasa disebabkan oleh kesalahan-kesalahan berbahasa. Pada gilirannya kesalahan-kesalahan berbahasa tersebut akan berakibat pada gangguan terhadap peristiwa komunikasi (kecuali pada pertistiwa tutur lawak, sandiwara, iklan, puisi). Kesalahan-kesalahan tersebut tidak terkecuali terjadi pula pada proses belajar mengajar. Dia juga menjelaskan bahwa ada kaitan yang saling memengaruhi antara kesalahan-kesalahan berbahasa dan (efektivitas) proses pembelajaran. Oleh 
karena itulah, hasil penelitain tentang kesalahan berbahasa sangat penting untuk menunjang Proses Belajar Mengajar (PBM). Misalnya, untuk (1) menentukan urutan bahan pengajaran, (2) memutuskan pemberian penekanan, (3) praktik yang diperlukan, (4) memberikan remidi dan laihan-latihan, (5) memilih butir-butir bahasa kedua untuk keperluan profisiensi pembelajar.

Hasil temuan para peneliti sebelumnya, meskipun yang dijadikan subjek penelitian adalah para siswa (SD dan SMA), menunjukkan bahwa kesalahan berbahasa masih banyak ditemukan di kalangan pelajar. Bukan tidak mungkin hal itu juga ditemukan di kalangan mahasiswa. Akan tetapi, tentu saja harus diverfikasi di lapangan. Penelitian ini juga menghipotesiskan masih cukup banyak kesalahan berbahasa di kalangan mahasiswa dalam berbagai aspek, misalnya aspek ejaan, penulisan kata, an struktur kalimat. Hal itu diyakini karena selama ini, menurut pengematan, bahasa pada umumnya dan bahasa Indonesia, khususnya dipandang tidak penting, remeh, gampang, yang penting tahu sama tahu. Ringkasnya abai terhadap norma bahasa. Untuk menjawab dan menganalisis jawaban responden di dalam penelitian ini digunakan teori/metode normatif, yaitu buku Pedoman Umum Ejaan Bahasa Indonesia dan Tata Bahasa Baku Bahasa Indonesia

\section{Metode Penelitian}

Sebelum menjelaskan tahapan penelitian ini, di sini disampaikan beberapa hal yang terkait dengan penyediaan dan analisisi data, serta penyajian hasil penelitian. Populasi penelitian ini adalah seluruh mahasiswa Fakultas Peternakan dan Pertanian, Universitas Diponegoro, Semarang; sedangkan populasi sasarannya adalah mahasiswa semester 2. Dari pupulasi sasaran tersebut, diambil 76 orang mahasiswa sebagai sampel. Dari 76 orang yang dijadikan sampel sekaligus dijadikan responden penelitian ini. Data dalam penelitian ini , sebagai tahap pertama, diperoleh dengan teknik angket. Angket yang dibagikan ke responden dilakukan melalui daring, yaitu ms team dan ms form. Selain angket, penelitian ini juga menggunakan metode wawancara melalui voice/video call. Tahap berikutnya adalah analisis data. Analisis data dilakukan melalui tahapan, yaitu (a) setelah data terkumpul dilakukan klasifikasi data, (b) mengelompokkan jawaban responden atas jawaban yang benar dan jawaban yang salah, (c) melakukan tabulasi , dan (d) melakukananalisis isi dengan menggunakan EBI dan tata bahasa baku sebagai alat untuk mengukur benar/salah jawababn reesponden. 


\section{Hasil dan Pemabahasan}

Setelah data terkumpul dan dianalisis ditemukan secara umum hal-hal seperti berikut. Pertama, nilai rata-rata menjawab soal dengan benar sebesar 54,54 \% dari 11 soal yang dikerjakan oleh 40 responden dengan nilai tertinggi81,81 \% atau menjawab dengan benar sebanyak 9 soal dan terendah dengan nilai 36,36 \% atau menjawab 4 soal yang benar.Kedua, jika

dilihat berdasarkan setiap butir soal yang dijawab dengan benar diperoleh hasil sebagai berikut

(1) untuk soal no 1 dijawab secara benar oleh 35 responden $(87,5 \%)$ dan 5 responden menjawab salah $(22,5 \%)$;

(2) untuk soal nomor 2, tidak satu pun responden yang menjawab benar $(0 \%)$;

(3) untuk soal nomor 3, sebanyak 1 responden (2,5\%) yang menjawab benar, sedangkan sisanya 39 responden $(87,50 \%)$ menjawab salah;

(4) untuk soal nomor 4, responden yang menjawab benar sebanyak 27 (67,50\%) responden menjawab benar, sedangkan sebanyak 13 responden $(32,50 \%)$ menjawab salah;

(5) untuk soal nomor 5, sebanyak 34 responden (85\%) menjawab dengan benar, sedangkan sisanya, yaitu sebanyak 6 responden $(15 \%)$ menjawab salah;

(6) untuk soal nomor 6, sebanyak 25 responden (62,50\%) menjawab dengana benar, sedangkan sisanya sebanyak 15 responden $(37,50 \%)$ menjawab salah;

(7) untuk soal nomor 7. sebanyak 39 responden $(97,50 \%)$ menjawab dengan benar, dan sebanyak 1 responden $(2,50 \%)$ salah dalam menjawab.;

(8) untuk soal nomor 8, dijawab dengan benar oleh 24 responden (60\%), dan 13 responden (40\%) menjawab salah;

(9) untuk sosal nomor 9, sebanyak 27 responden (67,50\%) menjawab benar, sedangkan sebanyak 13 responden $(22,50 \%)$ menjawab, tetapi salah;

(10) untuk soal nomor 10, sebanyak 16 responden (40\%) menjawab dengan benar, tetapi sebanyak 24 responden (60\%) jawabannya salah; dan

(11) untuk soal nomor 11, yang menjawab dengan benar sebanyak 1 responden (2,5\%), dan sebanyak 39 responden $(97,50 \%)$ menjawab, tetapi salah.

Ketiga, berikut disajikan uraian tiap soal dan jawaban responden yang benar.

Untuk butir soal nomor (1) adalah Meskipun sakit, tetapi dia tetap masuk kerja . Atas soal ini, sebagaimana hasil data di atas, 35 responden $(87,50 \%)$ menjawab dengan benar . Artinya, sebagian besar responden mengetahui/memahami kaidah penggunaan kata penghubung 
meskipun dan tetapi dan kaidah bahwa dalam suatu kalimat harus ada Subjeknya.Sekaligus juga memahami kaidah penggunaan tanda , (koma). Sebab, kalimat tersebut dapat diperbaiki menjadi (a) Meskipun sakit, dia tetap masuk kerja, (b) Dia sakit, tetapi tetap masuk keja, atau (c) dia tetap masuk kerja meskipun sakit.

Untuk soal nomor (2) Hampir setiap pagi jalan Ahmad Yani macet tidak satu pun responden yang menjawab dengan benar. Perbaikan yang dilakukan hanya pada penggunaan kata jalan menjadi Jalan (sehingga lengkapnya Jalan Ahmad Yani)

Untuk soal nomor (3) Aktfitas mahasiswa tidak terganggu meskpun ada kasus pendemik covid-19, hanya 1 responden yang menjawab dengan benar (Aktivitas mahasiswa tidak terganggu meskipun ada kasus pendemik covid-19, sedangkan 39 responden lainnya menjawab, tetapi salah.

Untuk soal nomor (4) Selamat hari ulang tahun RI ke 74 dijawab dengan benar oleh responden sebesar 67,50\%. Kalimat (4) yang betul menurut kaidah adalah (4a) Selamat hari ulang tahaun ke-74 Republik Indonesia.

Pada soal nomor (5) Bagi yang belum membayar UKT mohon mengajukan permohonan cuti kuliah, responden yang menjawab dengan benar sebanyak 85\%. Kalimat 5 dapat diubah menjadi (5a) Yang belum membayar UKT mohon mengajukan permohonan cuti kuliah atau (5b) Bagi yang belum membayar UKT, dimohon mengajukan permohonan cuti kuliah.

Untuk soal nomor (6) Ijasah SMA ku belum dilegalisir dijawab dengan benar oleh 62,50\% responden, yaitu menjadi kalimat (6a) Ijazah SMA-ku belum dilegalisasi, sedangkan untuk soal nomor (7) Prodak itu belum memenuhi standard kwalitas dijawab dengan benar oleh responden sebanyak 97,50\%, yaitu menjadi kalimat (7a) Produk itu belum memenuhi standar kualitas.

Untuk soal nomor (8) Dia sedang berdiskusi tentang PSSB dijawab dengan benar oleh responden sebanayak 60\%, sedangkan untuk soal nomor (9) Dia sangat pandai tetapi tetap rendah hati dijawab dengan benar oleh responden sebanyak 67,50\%. Pembetulan kalimat 8 dan 9 adalah kalimat (8a) dan (9a), yaitu (8a) Mereka sedang berdisksusi tentang PSSB dan (9a) Dia sangat pandai, tetapi tetap rendah hati.

Untuk soal nomor (10) Kerukunan umat antar agama harus terus diupayakan dan (11) Ibu sedang menanak nasi, responden yang menjawab benar untuk soal nomor 10 sebesar 40\%, tetapi untuk soal nomor 11 tidak satu pun responden yang menjawab dengan benar $(0 \%)$. 
Dari hasil dan jawaban responden yang ditemukan dalam penelitian ini dapat dipaparkan beberapa catatan. Kedua, untuk soal nomor 2. Ternyata, tidak satu pun responden yang menjawab benar. Hal ini dapat diduga karena selama ini pengajaran bahasa (pada jenjang pendidikan dasar dan menengah) sebelumnya lebih banyak diajarkan tentang bahasa, bukan tentang bagaimana berbahasa, Ketiga, untuk soal nomor 3 sebagian besar responden menjawab dengan benar. Artinnya, para mahasiswa FPP mengetahui sejumlah kosakata baku (aktivitas bukan aktifitas). Keempat, pada soal nomor 4 identik dengan soal nomor 2. Artinya, sebagian besar mahasiswa mampu menjawab soal tersebut dengan benar. Kelima, pada soal soal nomor 5 juga sebagian besar (85\%) mahasiswa mampu menjawab dengan benar. Hal ini diduga karena tipe soal ini relatif lebih sering dijadikan contoh dalam pembelajaran bahasa Indonesia. Keenam, untuk soal nomor 6 dapat dijawab dengan benar oleh 62,50 \%. Hal ini dapat dimaknai bahwa soal tersebut relatif mudah meski penegtahuan kata baku. Ketujuh, untuk soal nomor 7 responden yang mampu menjawab dengan benar mencapai angka sangat tinggi, yaitu 97,50 \%. Kedelapan, masih cukup banyak mahasiswa FPP belum mengetahui konsep Subjek, Predikat dengan baik. Kesembilan, untuk soal nomor 9 yang dapat menjawab dengan benar sebanyak 67,50\% dapat dimaknai mahasiswa FPP sudah cukup baik pengetahuan tentang kalaimat pertentangan dan penggunaan tanda koma (,). Kesepuluh, untuk soal nomor 10 responden yang menjawab dengan benar hanya 40\%. Hal ini dapat dimaknai bahwa mahasiswa FPP (60\%) belum cukup pengtahuannya tentang penulisan bentuk-bentuk gabung dan bentuk kata terpisah. Kesebelas,untuk soal nomor 11 hanya 1 reponden (2,50\%) yang menjawab dengan benar. Hal ini dapat disebabkan oleh sistem pengajaran bahasa yang selama ini lebih bersifat "tentang bahasa" belum tentang "bagaimana berbahasa". Akibatnya, ketika disodorkan kalimat yang "aneh" belum dapat memahaminya dengan baik. Akibatnya, jawaban mereka salah.

\section{Simpulan}

Dari uraian di atas dapat dicatat beberapa hal sebagai simpulan. Pertama, temuan ini menguatkan penelitian-penelitian sebelumnya, yaitu masih cukup banyaknya masyarakat (kaum terpelajar/pelajar) yang belum memahami dengan baik kaidah umum ejaan bahasa Indonesia dan tata bahasa bahasa Indonesia yang baikdan benar. Kedua, kesalahan-kesalahan itu meliputi kesalahan dalam bidang tanda baca, khususnya tanda koma (,), kesalahan dalam bidang penulisan kata baku, dan kesalahan dalam bidang struktur kalimat. Ketiga, jika dirata-rata, nilai 
jawaban responden yang benar dalam penelitian ini sebesar 54,54\% dengan nilai tertinggi responden yang menjawab benar $81,82 \%$, dan terendah sebesar 36,36 \%. Keempat, jumlah responden yang menjawab dengan benar untuk soal: nomor 1 sebesar 87,50\%; nomor 2 sebesar 0\%; nomor 3 sebesar 2,5\%; nomor 4 sebesar 67,50\%; nomor 5 sebesar 85\%; nomor 6 sebesar 62,50\%; nomor 7 sebesar 97,50\%; nomor 8 sebesar 60\%; nomor 9 sebesar 67,50\%; nomor 10 sebesar 40\%; dan nomor 11 sebesar 2,50\%. Kelima, pengetahuan mahasiswa tentang bahasa Indonesia tergolong cukup baik, tetapi pengetahuan tentang bagaimana berbahasa masih tergolong rendah. Jika dikaitkan dengan teori Bloom, maka aspek tertinggi yang dimiliki mahasiswa FPP baru pada taraf kognitif (konsep-konsep dasar bahaha Indonesia, khususnya tanda baca koma, kata-kata baku, dan penggunaan kata penghunung tetapi. Keenam, masih cukup banyaknya kesalahan mahasiswa dalam menjawab 11 soal yang disodorkan, diduga sistem belajar pad jenjang pendidikan dasar dan menengah belum mendorong peserta didik/pembelajar untuk aktif dan kreatif untuk "berbahasa"/terlatih mengungkapkan pikran dan atau perasaannya lewat tulisan/ucapan. Ketujuh, selama ini mata pelajaran/mata kuliah bahasa Indonesia dinilai kurang penting dibandingkan dengan mata pelajaran/mata kuliah, seperti matematika, bahasa Inggris, Fisika, Kimia, sehingga mereka umumnya abai dan mengganggap sepele pelajaran/mata kuliah bahasa Indonesia. Kedelapan, bisa saja bukan hanya karena mata pelajaran/mata kuliah bahasa Indonesia dianggap kurang penting, tetapi karena proses pembelajaran bahasa Indonesia tidak menarik sehingga para pembelajar (siswa/mahasiswa) menjadi kurang perhatian.

\section{Daftar Pustaka}

Alwi, Hasan, dkk. Tata bahasa baku bahasa ndonesia, Jakarta: Balai Pustaka, 1988.

Ariningsih, Nur Endah; Sumarwati; Kundaru Sabdono. Analisis kesalahan berbahasa indonesia dalam karangan eksposisi siswa SMA dalam Basastra, Jurnal Penelitian Bahasa, Sastra Indonesia, dan Pengajarannya, Vol.1, Nomor 1, h.40-53, 2012.

Badan Pengembangan dan Pembinaan Bahasa, Kementrian Pendidikan dan Kebudayaan RI. Pedoman umum ejaan bahasa indonesia, Jakarta, 2015.

Johan, Gio Mohamad.Analisis kesalahan berbahasa indonesia dalam proses diskusi siswa SD dalam Jurnal Penddidikan Bahasa dan Sastra, Vol,18 No.1, hlm.136-149, 2018.

Justiana, Monica. Kesalahan berbahasa pada majalah mimbar edisi juni-agustus 2016 dalam Simki-Pedagogia Vol.2, No.3, hlm. 1-12, 2018/2016.

Supriani, Reni; Ida Rahmadani Siregar. Penelitian analisis kesalahan berbahasa dalam Jurnal Edukasi Kultura, halm 67-76, Tanpa Tahun. 